Original Research

\title{
UJI EFEKTIVITAS DAN UJI STABILITAS FORMULASI MASKER GEL PEEL-OFF EKSTRAK METANOL KULIT BIJI PINANG YAKI (Areca vestiaria Giseke)
}

\author{
EFFECTIVENESS TEST AND STABILITY TEST FORMULATION OF PEEL-OFF \\ GEL MASK OF METHANOL EXTRACT YAKI BETEL NUT SKIN \\ (Areca vestiaria Giseke)
}

\author{
Dwi Setianingsih ${ }^{1 *}$, Marta Halim ${ }^{2}$ \\ ${ }^{1}$ Fakultas Farmasi, Universitas 17 Agustus 1945 Jakarta, Jakarta, Indonesia, 14350. \\ *E-mail: pharmartacist@gmail.com
}

\begin{abstract}
Abstrak
Kerusakan pada kulit akan mengganggu kesehatan manusia maupun penampilan sehingga kulit perlu dijaga dan dilindungi kesehatannya. Salah satu yang dapat menyebabkan kerusakan kulit adalah radikal bebas yang berupa sinar ultra violet. Dalam kondisi yang berlebih, sinar UV dapat menimbulkan beberapa masalah terhadap kulit, mulai dari kulit kemerahan, pigmentasi, bahkan dalam waktu lama menyebabkan resiko kanker. Buah pinang yaki mengandung senyawa-senyawa metabolit sekunder seperti alkaloid, flavonoid, triterpenoid, steroid, dan tanin yang memiliki sifat antioksidan sehingga memungkinkan untuk memberikan perlindungan terhadap sinar UV. Pada penelitian ini, dilakukan pengembangan berupa pembuatan sebanyak 3 formula masker peel off dengan konsentrai ekstrak kulit biji pinang yaki 5\% (FI), 7,5\% (FII), dan 10\% (FIII). Sebagai blanko (F0) sediaan dibuat tanpa ekstrak kulit biji pinang yaki. Sediaan masker gel peel-off ekstrak kulit biji pinang yaki memiliki efektivitas dalam melembabkan kulit dengan hasil adanya perbedaan signifikan antar formula, konsentrasi $10 \%$ menunjukkan efektivitas yang lebih baik dalam menjaga kelembapan kulit dengan perubahan nilai kadar $\mathrm{pH}$ kulit mencit mendekati $\mathrm{pH}$ normal rata-rata nilainya sebesar 6,194 setelah 28 hari pemakaian masker. Dari hasil uji evaluasi yang dilakukan bahwa pada uji organoleptik, homogenitas, viskositas, $\mathrm{pH}$, daya sebar, dan waktu sediaan mengering selama 28 hari pada suhu $4 \pm 2^{\circ} \mathrm{C}, 25 \pm 2^{\circ} \mathrm{C}$ dan suhu $40 \pm 2^{\circ} \mathrm{C}$. Hasil penelitian menunjukkan bahwa masingmasing formula sediaan gel masker peel off ekstrak kulit biji pinang yaki memiliki stabilitas yang baik selama penyimpanan.
\end{abstract}

Kata kunci : Areca vestiaria Giseke; Masker Gel Peel Off ; pH. 


\begin{abstract}
Damage to the skin will interfere with human health and appearance so the skin needs to be maintained and protected health. One that can cause skin damage is free radicals in the form of ultraviolet light. Under excessive conditions, UV rays can cause several problems with the skin, ranging from skin redness, pigmentation, and even for a long time causing the risk of cancer. Yaki areca nut contains secondary metabolite compounds such as alkaloids, flavonoids, triterpenoids, steroids, and tannins which have antioxidant properties that make it possible to provide protection against UV rays. In this research, development was carried out in the form of making 3 peel off mask formulas with 5\% (FI), 7.5\% (FII), and 10\% (FIII) areca nut extract extracts. As blank (FO), preparations are made without extract of yaki areca nut shell. The peeloff gel mask extract of yaki seed skin has effectiveness in moisturizing the skin with the result of a significant difference between formulas, a concentration of $10 \%$ shows a better effectiveness in maintaining skin moisture with changes in the $\mathrm{pH}$ value of mice's skin levels close to normal $\mathrm{pH}$ average values amounted to 6.194 after 28 days of using the mask. From the results of evaluation tests carried out that the organoleptic test, homogeneity, viscosity, $p H$, spreadability, and preparation time to dry for 28 days at a temperature of $4 \pm 2{ }^{\circ} C, 25 \pm 2{ }^{\circ} C$ and a temperature of $40 \pm 2{ }^{\circ} \mathrm{C}$. The results showed that each of the peel off gel mask gel formula form the yaki areca nut extract had good stability during storage.
\end{abstract}

Keywords: Areca vestiaria Giseke; Masker Gel Peel Off ; pH.

\title{
PENDAHULUAN
}

Tubuh manusia mempunyai berbagai cara untuk melakukan proteksi. Pertahanan pertama yang dimiliki oleh tubuh adalah barier mekanik, dengan adanya kulit. Kulit merupakan organ yang melapisi seluruh permukaan tubuh makhluk hidup dan mempunyai fungsi untuk melindungi dari pengaruh luar [1]. Kerusakan pada kulit akan mengganggu kesehatan manusia maupun penampilan sehingga kulit perlu dijaga dan dilindungi kesehatannya. Salah satu yang dapat menyebabkan kerusakan kulit adalah radikal bebas yang berupa sinar ultra violet. Dalam kondisi yang berlebih, sinar UV dapat menimbulkan beberapa masalah terhadap kulit, mulai dari kulit kemerahan, pigmentasi, bahkan dalam waktu lama menyebabkan resiko kanker [2]. Oleh karena itulah diperlukan penangkal ancaman bahaya radikal bebas yang dapat mencegah kerusakan pada kulit.

Kulit normal memiliki $\mathrm{pH}$ antara 5-6,5, dimana kondisi $\mathrm{pH}$ yang asam ini berfungsi sebagai pertahanan kulit dari gangguan luar, proteksi terhadap infeksi mikroorganisme. Seiring penuaan kulit, $\mathrm{pH}$ kulit akan semakin basa [3].

Antioksidan adalah senyawa kimia yang dapat digunakan untuk melindungi komponen biologi seperti lipida, protein, vitamin dan DNA melalui perlambatan kerusakan, ketengikan atau perubahan warna yang disebabkan oleh oksidasi. Antioksidan mampu bertindak sebagai penyumbang radikal hidrogen atau dapat bertindak sebagai aseptor radikal bebas sehingga dapat menunda tahap inisiasi [4]. 
Salah satu bahan alam yang memiliki kandungan antioksidan yang baik adalah pinang yaki. Pinang yaki (Areca vestiaria Giseke) merupakan salah satu tanaman hias yang tumbuh di Sulawesi Utara yang dimanfaatkan sebagai obat untuk penyakit diabetes serta diare dan juga dipakai sebagai obat kontrasepsi [5]. Buah pinang yaki mengandung senyawa-senyawa metabolit sekunder seperti alkaloid, flavonoid, triterpenoid, steroid, dan tanin yang memiliki sifat antioksidan sehingga memungkinkan untuk memberikan perlindungan terhadap sinar UV [6].

Kulit biji pinang yaki (Areca vestiaria Giseke) dipilih karena memiliki kandungan antioksidan sebesar 8,3 ppm [7]. Itu menandakan bahwa antioksidan pada kulit biji pinang yaki tergolong dalam antioksidan yang sangat kuat yaitu nilai IC50 $<50 \mu \mathrm{g} / \mathrm{mL}$ [8].

\section{METODE}

\section{Sampel (Bahan) Penelitian}

Ekstrak kulit biji pinang yaki, polivinil alkohol, hidroksipropil metilselulosa, metanol, metil paraben, propil paraben, propilenglikol, etanol $96 \%, \mathrm{FeCl}_{3}, \mathrm{H}_{2} \mathrm{SO}_{4}$, pereaksi dragendrof, pereaksi meyer, pereaksi wagner, pereaksi bouchard, aquadest dan produk masker peel-off Sariayuß.

\section{Prosedur kerja}

\section{Preparasi Sampel}

Sampel pinang yaki diambil dan dicuci, lalu dipisahkan antara kulit buah, kulit biji dan biji. Kemudian, diambil bagian kulit biji pinang sebagai bahan utama. Selanjutnya, dikering anginkan selama 7 hari. Sampel yang kering dihaluskan dengan menggunakan blender hingga berbentuk serbuk.

\section{Ekstraksi sampel}

Sampel kulit pinang yaki yang telah dihaluskan sebanyak 50 gram diekstraksi secara sokletasi dengan pelarut metanol sebanyak $500 \mathrm{~mL}$. Proses ekstraksi dilakukan 2,5 jam hingga pelarut yang terdapat di dalam labu tidak berwarna. Hasil ekstrak dievaporasi pada suhu $50^{\circ} \mathrm{C}$ sampai diperoleh ekstrak metanol. Rendemen ekstrak kulit biji buah pinang yaki dihitungan dengan mengunakan rumus berikut :

$$
\text { Rendemen }=\frac{\text { berat ekstrak kental }}{\text { berat awal simplisia }} \times 100 \%
$$

\section{Penyiapan Hewan Uji}

Dalam 5 kelompok, tiap kelompok terdiri dari 5 ekor mencit, kelompok 1 adalah kelompok perlakuan yang diberikan kontrol negatif dengan pemberian masker peel-off tanpa ekstrak kulit biji pinang yaki (F0), kelompok II adalah kelompok perlakuan yang diberikan kontrol positif masker brand Sariayu, kelompok III adalah kelompok perlakuan yang diberikan masker peel-off ekstrak kulit biji pinang yaki dengan konsentrasi $5 \%$ (F1), kelompok IV kelompok perlakuan yang diberikan masker peel-off ekstrak kulit biji pinang yaki dengan konsentrasi 7,5 \% (F2), kelompok $\mathrm{V}$ kelompok perlakuan yang diberikan masker peel-off ekstrak kulit biji pinang yaki dengan konsentrasi $10 \%(\mathrm{~F} 3)$. 
Selama 1 minggu mencit diadaptasikan dalan kandang Laboratorium Hewan Coba Univesitas 17 Agustus 1945 Jakarta sebelum diberikan perlakuan. Selama masa adaptasi mencit diberikan makanan dan minuman yang sama dan diamati secara rutin terhadap keadaan umum dan penimbangan berat badan mencit. Mencit dengan ciri-ciri umum yaitu bulu berdiri, tidak aktif dan mata tidak jernih, tidak dikutsertakan dalam penelitian.

\section{Formulasi Sediaan Masker Gel Peel Off Ekstrak Metanol Kulit Biji Pinang Yaki (Areca vestiaria Giseke).}

\begin{tabular}{|c|c|c|c|c|c|c|}
\hline \multirow{2}{*}{ Bahan } & \multicolumn{4}{|c|}{ Formula (b/v) } & \multirow{2}{*}{ Fungsi } & \multirow{2}{*}{$\begin{array}{c}\text { Masker Peel-Off } \\
\text { Sariayu }{ }^{\circledR} \\
\text { (Kontrol Positif) }\end{array}$} \\
\hline & F0 & F1 & $\mathbf{F} 2$ & F3 & & \\
\hline Ekstrak Kulit Biji Pinang Yaki & - & $5 \%$ & $7,5 \%$ & $10 \%$ & Antioksidan & \multirow{9}{*}{$\begin{array}{l}\text { Aqua, Alcohol, } \\
\text { Polyvinyl Alcohol, } \\
\text { PEG, Ethyl } \\
\text { ascorbic } \\
\text { acid,Glycerine, } \\
\text { Matricaria } \\
\text { Flower Water, } \\
\text { Lemon Extract, } \\
\text { Fragrance,dll. }\end{array}$} \\
\hline Polivinil Alkohol & 10 & 10 & 10 & 10 & Gelling Agent & \\
\hline Hidroksipropil Metilselulosa & 2 & 2 & 2 & 2 & $\begin{array}{l}\text { Peningkat } \\
\text { Viskositas }\end{array}$ & \\
\hline Propilenglikol & 15 & 15 & 15 & 15 & Humektan & \\
\hline Metil Paraben & 0,2 & 0,2 & 0,2 & 0,2 & Pengawet & \\
\hline Propil Paraben & 0,02 & 0,02 & 0,02 & 0,02 & Pengawet & \\
\hline Etanol 96\% & 10 & 10 & 10 & 10 & Pelarut & \\
\hline Pengaroma Cokelat & $3 \mathrm{gtt}$ & $3 \mathrm{gtt}$ & $3 \mathrm{gtt}$ & $3 \mathrm{gtt}$ & Pengharum & \\
\hline Akuades & $\begin{array}{c}\text { Ad } \\
100 \mathrm{ml}\end{array}$ & $\begin{array}{c}\text { Ad } \\
100 \mathrm{ml}\end{array}$ & $\begin{array}{c}\text { Ad } \\
100 \mathrm{ml}\end{array}$ & $\begin{array}{c}\text { Ad } \\
100 \mathrm{ml}\end{array}$ & Pelarut & \\
\hline
\end{tabular}

\section{Pembuatan Masker Gel Peel Off Ekstrak Metanol Kulit Biji Pinang Yaki (Areca vestiaria Giseke).}

Formula terdiri dari polivinil alkohol, hidroksipropil metilselulosa, propilenglikol, ekstrak metanol biji pinang yaki (Areca vestiaria Giseke) 5\%; 7,5\%;10\%, metil paraben, propil paraben, dan air ad $100 \mathrm{~mL}$. Polivinil alkohol dan hidroksipropil metilselulosa, dikembangkan dalam akuades suhu $90^{\circ} \mathrm{C}$ di dalam lumpang panas dengan pengadukan konstan hingga mengembang sempurna (Campuran 1), kemudian metil paraben dan propil paraben dilarutkan dalam etanol 96\% (Campuran 2). Propilenglikol, campuran 1 dan campuran 2 dimasukan secara berturut-turut kemudian diaduk hingga homogen. Setelah itu ditambahkan ekstrak yang sebelumnya telah dilarutkan dalam akuades sedikit demi sedikit, lalu diaduk hingga homogen. 


\section{Evaluasi Fisika Sediaan Masker Gel Peel Off}

Pengujian sifat fisik masker gel yang telah dibuat meliputi pengamatan perubahan organoleptis, pengukuran viskositas, pengukuran $\mathrm{pH}$, pengujian waktu sediaan mengering, pengujian daya sebar selama 28 hari pada kondisi suhu penyimpanan yang berbeda, yaitu pada suhu $4^{\circ} \mathrm{C}, 25^{\circ} \mathrm{C}$, dan $40^{\circ} \mathrm{C}$ dan pengujian iritasi sediaan masker peel off.

\section{Uji Iritasi}

Uji iritasi dilakukan terhadap 15 orang relawan dengan teknik patch test yaitu tempel terbuka yang dilakukan dengan mengoleskan sediaan (F1, F2, dan F3) seluas $2,5 \mathrm{~cm}^{2}$ pada punggung tangan sukarelawan. Uji keamanan dilakukan selama satu kali dalam sehari selama dua hari berturut turut setelah pembuatan dan pada hari terakhir penyimpanan untuk masingmasing sediaan. Gejala yang timbul diamati, umumnya iritasi akan segera ditunjukkan dengan adanya reaksi kulit sesaat setelah pelekatan atau penyentuhan pada kulit, iritasi demikian disebut iritasi primer. Tetapi jika reaksi ini timbul beberapa jam setelah penyentuhan atau pelekatan pada kulit, maka iritasi ini disebut iritasi sekunder [9].

\section{Uji Efektivitas Sediaan}

Pengujian efektivitas pengaruh $\mathrm{pH}$ kulit dilakukan kepada sebanyak 25 mencit dan dibagi menjadi 5 kelompok, yaitu: Kelompok I diberi masker peel-off tanpa ekstrak metanol kulit biji pinang yaki, Kelompok II diberi masker peel-off dengan ekstrak metanol kulit biji pinang yaki konsentrasi $5 \%$, Kelompok III diberi masker peel-off dengan ekstrak metanol kulit biji pinang yaki konsentrasi 7,5 \%, Kelompok IV diberi masker peel-off ekstrak metanol kulit biji pinang yaki dengan konsentrasi $10 \%$, Kelompok diberi masker peel-off Sariayu ${ }^{\circledR}[10]$.

Rambut pada punggung mencit dicukur, kemudian diolesi masker gel peel off setiap hari dan diberikan paparan sinar UV-B selama 4 minggu dan diamati perubahan $\mathrm{pH}$ kulit yang terjadi.

\section{Analisis Data}

Data hasil penelitian dianalisis dengan menggunakan metode statistik program SPSS (Statistical and Service Solution) 16. Data terlebih dahulu dianalisis distribusinya menggunakan Shapiro-Wilk Test, Uji Homogenitas Levene's Test, Anova One Way dilanjutkan uji Least Significant Difference (LSD). Selanjutnya data dianalisis menggunakan Kruskal-Wallis Test untuk mengetahui efektivitas anti aging pada kulit hewan coba diantara formula. Selanjutnya untuk menganalisis formula mana yang berbeda selama 28 hari perawatan digunakan MannWhitney Test. 


\section{HASIL DAN PEMBAHASAN}

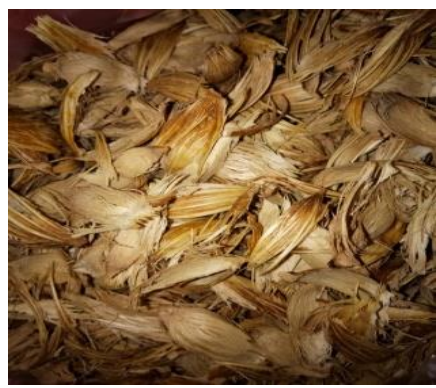

(i)

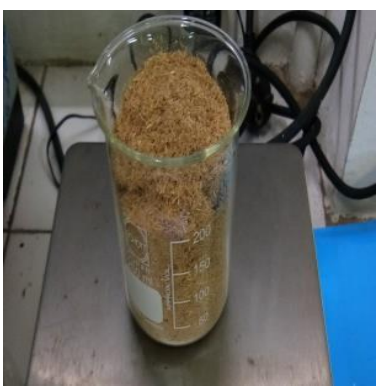

(ii)

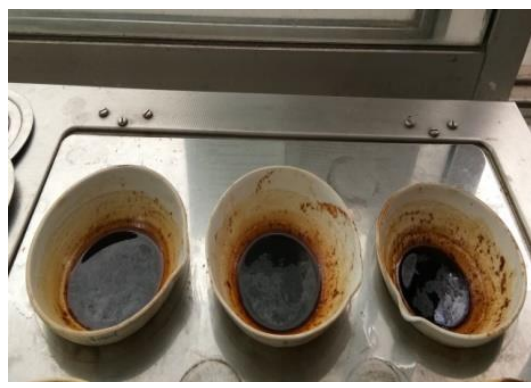

(iii)

Gambar 1. Kulit biji pinang yaki kering (i), serbuk kulit biji pinang yaki (ii), ekstrak kulit biji pinang yaki (iii).

Penelitian ini menggunakan sampel kulit biji pinang yaki yang diperoleh dari Balai Penelitian Tanaman Obat dan Rempah (Balitro) Bogor. Buah pinang yaki yang telah diperoleh sebagian dideterminasi dan sisanya dikering anginkan pada suhu ruangan. Determinasi bertujuan untuk mengetahui keaslian tumbuhan yang digunakan dalam sebuah penelitian. Metode ekstraksi yang digunakan pada penelitian ini adalah sokletasi. Alasan ini dipilih karena dengan adanya pemanasan dapat meningkatkan kemampuan untuk mengekstraksi senyawa-senyawa yang tidak larut dalam suhu kamar, sehingga aktivitas penarikan senyawa lebih maksimal. Pelarut yang selalu bersikulasi dalam proses kontak dengan simplisia juga menyebabkan tingginya rendemen yang diperoleh. Selain disebabkan oleh pemanasan, ukuran sampel juga mempengaruhi hasil rendemen. Semakin halus bahan yang digunakan, maka semakin tinggi juga randemen yang dihasilkan [11].

Selama proses sokletasi berlangsung alasan mengapa digunakan pelarut metanol karena pelarut metanol mampu menarik senyawa fenolik, flavonoid dan tanin ${ }^{[13]}$, selain itu juga alasannya berkaitan dengan tumbuhan yang dipakai dalam penelitian ini yaitu pinang yaki tedapat kandungan flavonoid, pelarut metanol adalah salah satu pelarut yang dapat mengekstraksi golongan semua flavonoid dan juga salah satu pelarut yang lebih polar digunakan untuk mengekstraksi glikosida flavonoid [13]. Proses ekstraksi dalam penelitian ini menghasilkan rendemen sebesar 84,6 g $(8,74 \%)$.

Setelah didapatkan ekstrak metanol kulit biji pinang yaki, perlu dilakukan pemeriksaan karakteristik ekstrak meliputi uji organoleptis, pengukuran susut pengeringan, kadar air, kadar abu, kadar sisa pelarut serta skrining fitokimia. 
1. Uji Karakteristik Ekstrak Metanol Kulit Biji Pinang Yaki (Areca vestiaria Giseke).

Tabel 1. UJi Karakteristik Ekstrak Metanol Kulit Biji Pinang Yaki (Areca vestiaria Giseke).

\begin{tabular}{|l|l|}
\hline \multicolumn{1}{|c|}{ Uji Karakteristik } & \multicolumn{1}{c|}{ Ekstrak Metanol Kulit Biji Pinang Yaki } \\
\hline Organoleptis : & Kental \\
a. Bentuk & Cokelat Tua \\
b. Warna & Aroma cokelat \\
c. Bau & $8,74 \%$ \\
\hline Rendemen & $4,73 \%$ \\
\hline Kadar Air & $3,5 \%$ \\
\hline Kadar Abu & $3,04 \%$ \\
\hline Susut pengeringan & 0,9991 \\
\hline Kadar Sisa Pelarut Metanol &
\end{tabular}

\section{Skrining Fitokimia}

Tabel 2. Hasil Skrining Metanol Kulit Biji Pinang Yaki (Areca vestiaria Giseke).

\begin{tabular}{|c|c|c|c|}
\hline No. & Kandungan Kimia & Perlakuan & Hasil \\
\hline 1 & Alkaloid & $\begin{array}{l}\left(\mathrm{CHCl}_{3}+\mathrm{NH}_{4} \mathrm{OH}+\mathrm{HCl}\right) \\
+ \text { Bouchardat } \rightarrow \text { Cokelat } \\
+ \text { Dragendrof } \rightarrow \text { Jingga } \\
+ \text { Mayer } \rightarrow \text { Putih }\end{array}$ & + \\
\hline 2 & Saponin & $\mathrm{H}_{2} \mathrm{O}$ kocok $\rightarrow$ busa & + \\
\hline 3 & Tanin & $\mathrm{FeCl}_{3} \rightarrow$ Hjiau Tua & + \\
\hline 4 & Fenolik & $\mathrm{NaOH} 10 \% \rightarrow$ Merah & + \\
\hline 5 & Flavonoid & Logam $\mathrm{MgO}+\mathrm{HCl}(\mathrm{P})+$ Amilalkohol $\rightarrow$ Merah & + \\
\hline 6 & Triterpenoid & $\begin{array}{l}\text { Asam asetat anhidrat }+\mathrm{CHCl}_{3}+\mathrm{H}_{2} \mathrm{SO}_{4}(\mathrm{P}) \rightarrow \text { cincin } \\
\text { hijau/ merah }\end{array}$ & + \\
\hline 7 & Steroid & $\begin{array}{l}\text { Asam asetat anhidrat }+\mathrm{CHCl}_{3}+\mathrm{H}_{2} \mathrm{SO}_{4}(\mathrm{P}) \rightarrow \text { cincin } \\
\text { biru/ ungu }\end{array}$ & - \\
\hline 8 & Glikosida & $\begin{array}{l}\text { Metanol }+\mathrm{H}_{2} \mathrm{SO}_{4} \text { pekat }+ \text { Asam asetat anhidrat } \rightarrow \\
\text { biru/ hijau }\end{array}$ & + \\
\hline
\end{tabular}




\section{Evaluasi Mutu Fisik Sediaan Masker Peel-Off}

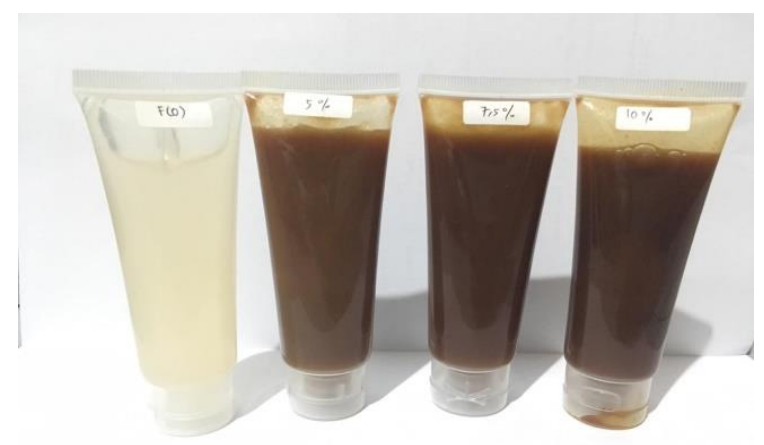

Gambar 3. Sediaan Masker Peel-offEkstrak Kulit Biji Pinang Yaki

Sediaan masker peel-off yang telah dibuat diuji stabilitasnya, dengan menyimpan sediaan pada 3 suhu berbeda, yaitu pada suhu $4^{\circ} \mathrm{C}, 25^{\circ} \mathrm{C}$ dan $40^{\circ} \mathrm{C}$. Setiap hari ke- $0,7,14,21,28$ diuji organoleptik, $\mathrm{pH}$, viskositas dan waktu sediaan mengering. Data hasil pengujian diuji statistik dengan menggunakan Anova one-way.

Masker peel-off esktrak metanol kulit biji pinang yaki berwarna cokelat tua dengan aroma cokelat. Formula yang disimpan pada suhu $4^{\circ} \mathrm{C}, 25^{\circ} \mathrm{C}, 40^{\circ} \mathrm{C}$ tidak terjadi perubahan bau. Perbedaan konsentrasi ekstrak pada setiap formula menyebabkan perbedaan warna, dimana semakin besar konsentrasi warna sediaan masker peel-off semakin gelap. Hasil uji organoleptis pada semua formula pada kondisi suhu ruang, suhu rendah maupun suhu tinggi, tidak menunjukkan adanya perubahan hingga akhir penyimpanan yakni pada minggu keempat. Hal ini menunjukan, bahwa sediaan masker peel-off biji kulit pinang yaki pada penelitian ini dikatakan stabil.

Hasil pemeriksaan homogenitas terhadap sediaan masker gel peel-off ekstrak kulit biji pinang yaki menunjukkan bahwa semua sediaan tidak memperlihatkan adanya butir-butir kasar pada saat sediaan dioleskan pada kaca transparan. Hal ini menunjukkan bahwa sediaan yang dibuat memiliki susunan yang homogen.

Pengukuran viskositas dilakukan pada minggu awal (hari ke-7) dan minggu terakhir (hari ke-28) yang diuji pada suhu ruang, suhu rendah dan suhu tinggi. Pemeriksaan viskositas dilakukan dengan menggunakan Viskometer Brookfield dengan nomor spindel 64 dan kecepatan rpm 12. Hasil pengamatan sediaan pada suhu ruang menunjukkan bahwa pada minggu ke empat, semua formulasi mengalami penurunan nilai viskositas dibandingkan dengan minggu pertama. Berdasarkan hasil uji ANOVA pada viskositas sediaan diperoleh nilai signifikan < 0,05 yang berarti terdapat perbedaan bermakna viskositas pada setiap formula dengan perbedaan suhu penyimpanan selama 28 hari. 
Hasil pengamatan sediaan pada suhu tinggi menunjukkan hasil yang berbeda dengan sediaan yang disimpan pada suhu ruang, dimana pada minggu ke-empat formula 0 (kontrol negatif), formula $1(5 \%)$, formula $2(7,5 \%)$ dan formula $4(10 \%)$ mengalami penurunan nilai viskositas dibandingkan dengan minggu pertama.

Hal ini membuktikan bahwa lama penyimpanan berpengaruh pada viskositas, karena semakin lama waktu penyimpanan, maka semakin lama juga sediaan terpengaruh oleh lingkungan, misalnya udara. Kemasan yang kurang kedap dapat menyebabkan sediaan menyerap uap air dari luar, sehingga menambah volume air dalam sediaandan viskositas semakin menurun.

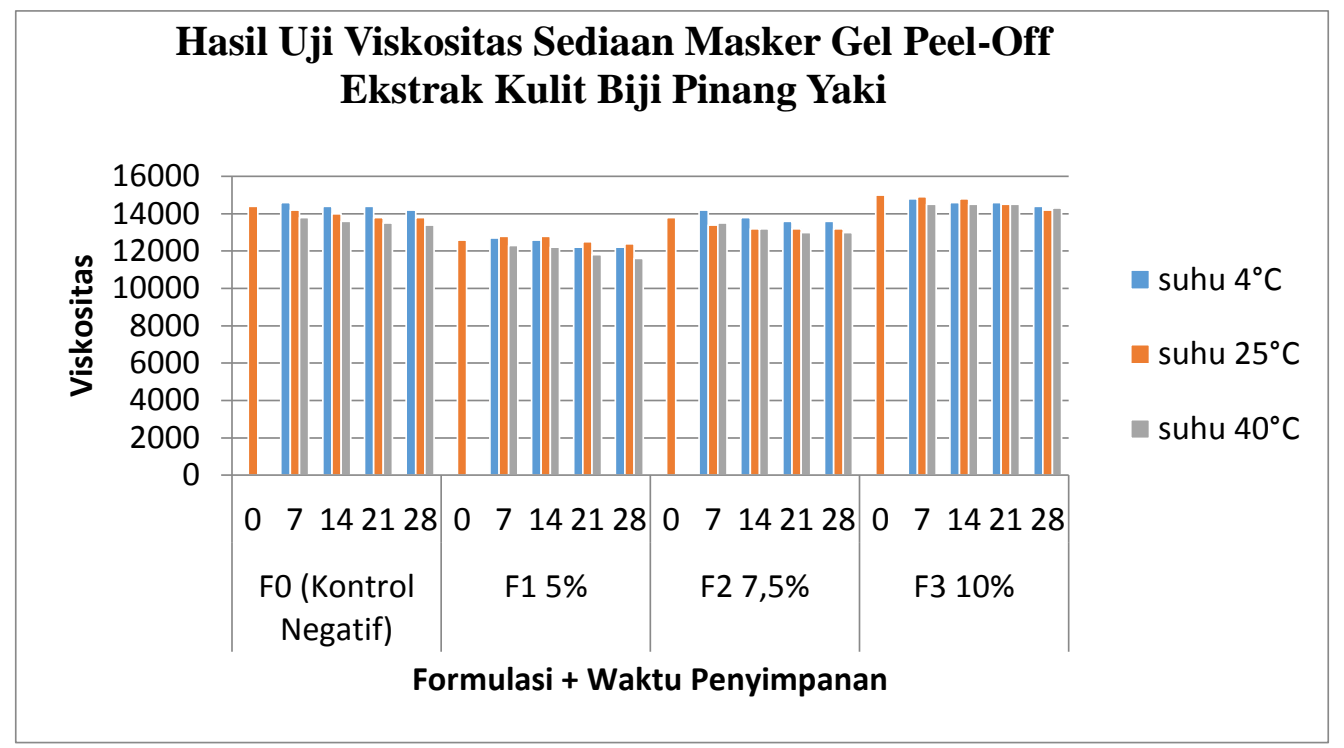

Pemeriksaan $\mathrm{pH}$ pada sediaan masker gel peel-off, didapatkan $\mathrm{pH}$ berkisar antara 5,6-5,92. Perubahan $\mathrm{pH}$ pada ketiga formula masker peel-off ekstrak kulit biji pinang ini tidak signifikan, pada penelitian ini menunjukkan bahwa semakin banyak jumlah ekstrak kulit biji pinang yaki yang ditambahkan maka $\mathrm{pH}$ sediaan semakin menurun atau dengan kata lain $\mathrm{pH}$ semakin asam. Berdasarkan hasil uji ANOVA pada $\mathrm{pH}$ sediaan diperoleh nilai signifikan >0,05 yang berarti tidak terdapat perbedaan bermakna $\mathrm{pH}$ pada setiap formula dengan perbedaan suhu penyimpanan selama 28 hari. Hal tersebut menunjukkan bahwa $\mathrm{pH}$ sediaan stabil selama penyimpanan. Meskipun terjadi penurunan pada $\mathrm{pH}$, tetapi sediaan tersebut masih aman digunakan. Dimana $\mathrm{pH}$ sediaan ini masih dalam $\mathrm{pH}$ fisiologis kulit yaitu 4,5-6,5 [14].

Pengaruh perubahan suhu juga mempengaruhi $\mathrm{pH}$ sediaan masker gel peel-off, dimana pada suhu tinggi $\left(40^{\circ} \mathrm{C}\right)$ semua formula mengalami kenaikan $\mathrm{pH}$, maka ini menunjukan bahwa semakin tinggi suhu $\mathrm{pH}$ akan semakin naik. 


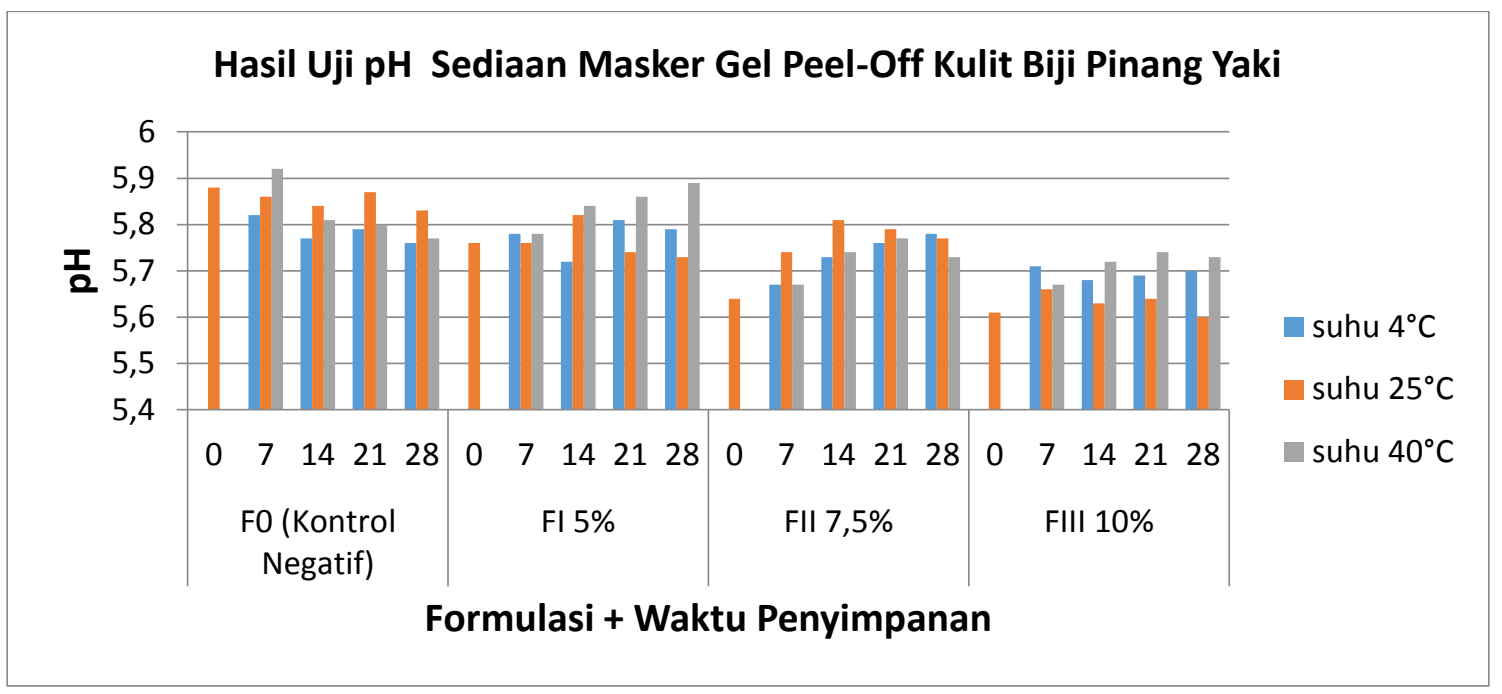

Hasil uji daya sebar sediaan masker gel peel-off ekstrak kulit biji pinang yaki menunjukkan masker gel peel-off memiliki daya sebar 5,53-5,97 cm. Uji daya sebar memiliki tujuan untuk melihat kemampuan menyebarnya gel pada permukaan kulit dimana diharapkan gel mampu menyebar dengan mudah ditempat yang dioleskan tanpa diberikan tekanan yang berarti. Daya sebar yang dihasilkan pada semua formulasi gel menunjukkan bahwa semakin lama penyimpanan maka daya sebar gel semakin meningkat. Daya sebar gel yang baik yaitu antara 5-7 cm [15]. Berdasarkan hasil uji ANOVA pada uji daya sebar diperoleh nilai signifikan >0,05 yang berarti tidak terdapat perbedaan bermakna kemampuan daya sebar pada setiap formula dengan perbedaan suhu penyimpanan selama 28 hari. Hal tersebut menunjukkan bahwa sediaan masker gel memiliki daya sebar yang baik selama penyimpanan.

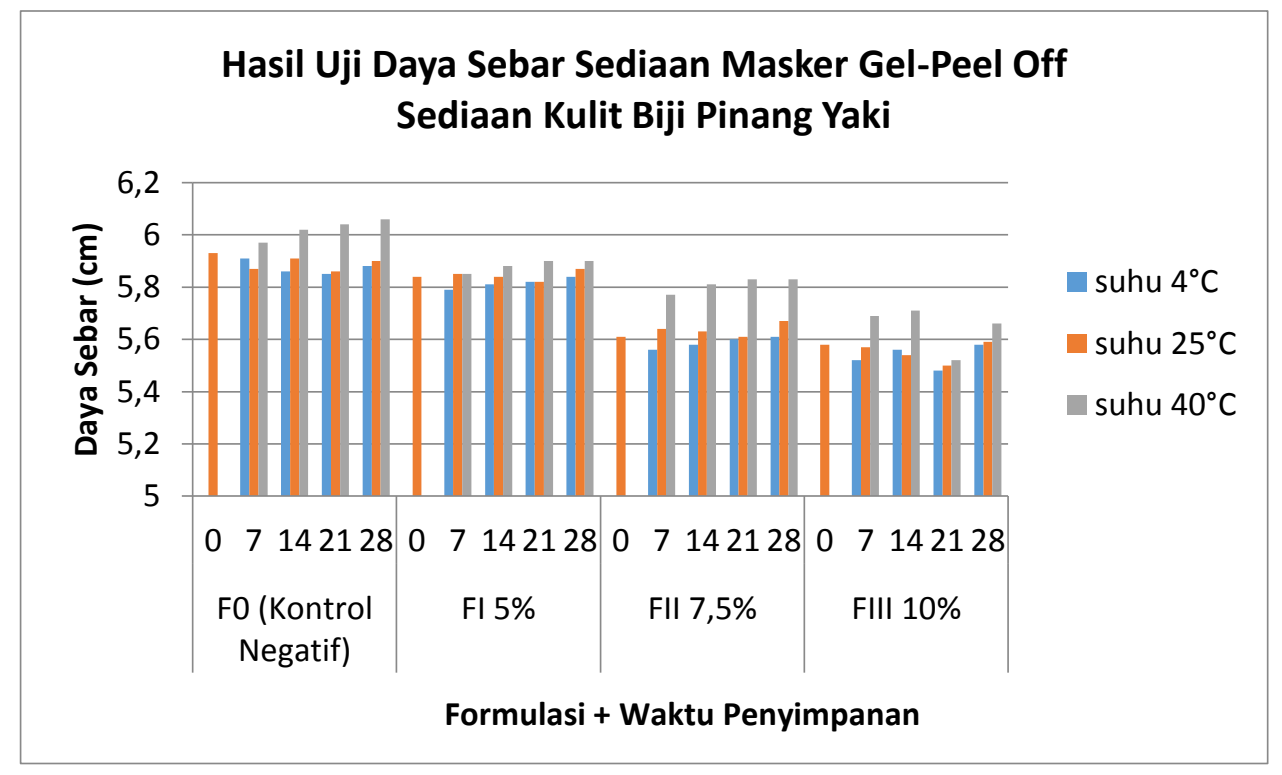


Hasil pengujian waktu sediaan mengering masker gel peel-off ekstrak kulit biji pinang yaki membutuhkan waktu 22,6 menit -26,6 menit. Pengujian waktu pengeringan terhadap sediaan dilakukan dengan mengamati waktu yang diperlukan sediaan untuk mengering, yaitu waktu dari saat mulai dioleskannya masker gel peel-off hingga benar-benar terbentuk lapisan yang kering [18]. Hasil yang diperoleh menunjukkan bahwa semakin lama penyimpanan, maka waktu yang dibutuhkan sediaan masker gel peel-off untuk mengering semakin meningkat.

Berdasarkan hasil uji ANOVA pada waktu mengering sediaan diperoleh nilai signifikan $<0,05$ yang berarti terdapat perbedaan bermakna waktu mengering pada setiap formula dengan perbedaan suhu penyimpanan selama 28 hari. Hal ini dapat disebabkan karena sediaan masker gel peel-off mengandung propilenglikol yang bersifat higroskopis dengan afinitas yang tinggi untuk menarik dan menahan molekul air dan menjaga kestabilan dengan cara mengabsorbsi lembab dari lingkungan dan mengurangi penguapan air dari sediaan [17].

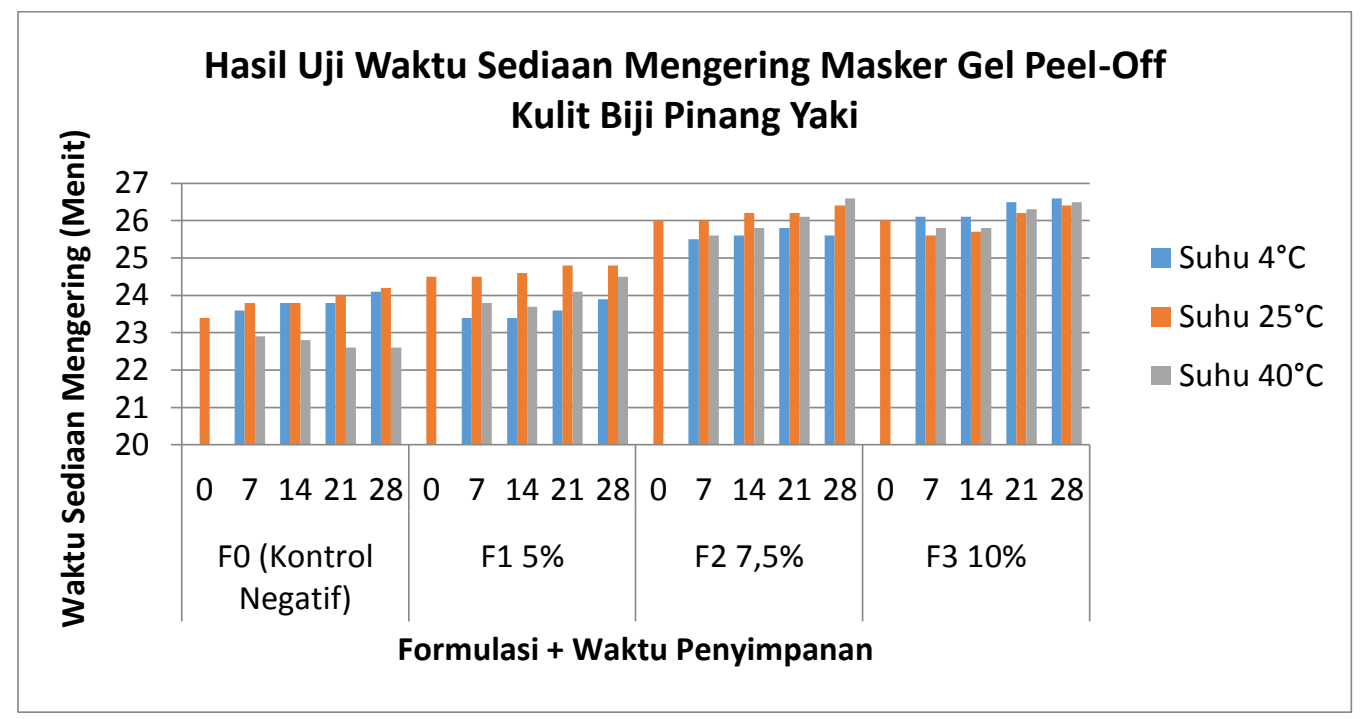

\section{Uji Iritasi}

Uji dilakukan dengan cara mengoleskan sediaan masker gel peel-off pada lengan bawah bagian dalam, menunjukkan bahwa semua sukarelawan memberikan hasil yang sebagian besar negatif (tidak menimbulkan iritasi) terhadap parameter reaksi iritasi dan terdapat 1 sukarelawan yang mengalami sedikit kemerahan pada formulasi ke-3 (10\%) hal tersebut dapat disebabkan karena tingkat kesensitifan kulit yang berbeda-beda dan konsentrasi nilai ekstrak juga mempengaruhi terhadap tingkat iritasi pada kulit. Parameter yang diamati yaitu adanya kulit kemerahan, gatal-gatal, ataupun adanya pembengkakan. Hasil uji iritasi tersebut disimpulkan bahwa sediaan masker gel peel-off cukup aman untuk digunakan [14]. 


\section{Uji Efektivitas Sediaan Masker Gel Peel-Off}

Berdasarkan hasil yang diperoleh diketahui bahwa kelompok perlakuan III memiliki perbedaan yang signifikan dengan kelompok perlakuan I, II dan kelompok kontrol.

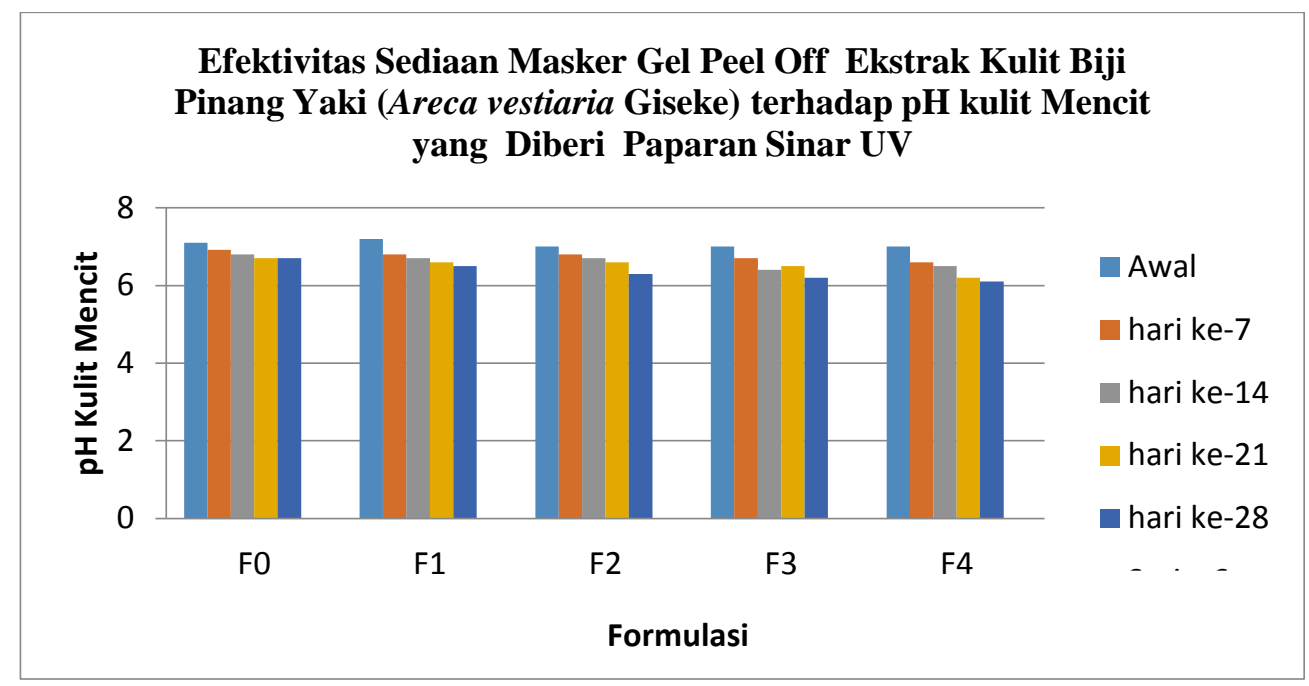

Hasil ini menunjukkan bahwa pH kulit dapat dipertahankan dengan adanya ekstrak kulit biji pinang yaki (Areca vestiaria Giseke) dalam masker gel peel off yang digunakan. Hal ini dikarenakan ekstrak kulit biji pinang yaki mengandung fitoantioksidan yang tinggi dilihat dari nilai Inhibition Concentration 50\% (IC50) kurang dari 50 yaitu sebesar 8,3 ppm [7].

Pada pengujian efektivitas, kulit mencit yang sudah diberikan masker peel-off blangko (tanpa kandungan ekstrak metanol kulit biji pinang yaki) kemudian diberikan paparan sinar UV selama 1 jam dan diperoleh hasil rata-rata selama pemakaian selama 28 hari sebesar 6,74. Dan pada kelompok mencit yang diberikan masker peel-off Sariayu ${ }^{\circledR}$ diperoleh kadar $\mathrm{pH}$ kulit sebesar 6,12. Sedangkan pada mencit yang diberi masker dengan formulasi 5\% ; 7,5\% dan $10 \%$ diperoleh kadar $\mathrm{pH}$ kulit dengan rata-rata secara berturut-turut sebesar 6,$51 ; 6,30 ; 6,12$. Dari hasil nilai $\mathrm{pH}$ kulit yang diperoleh bahwa, semakin besar konsentrasi ekstrak kulit biji pinang yaki pada sediaan masker peel-off semakin terjadi penurunan nilai $\mathrm{pH}$ kulit mendekati $\mathrm{pH}$ normal kulit yang relatif asam yaitu 4,5-6,5 [14].

Pada penelitian Antioksidan berperan sebagai scavenging agent yang berperan untuk mencegah perusakan lipid interseluler dan komponen mantel asam oleh ROS yang dihasilkan oleh sinar UV [17]. Ketika perusakan lipid interseluler dan mantel asam dapat dicegah, maka hidrasi kulit dapat terjaga dan kulit dapat bekerja secara normal. Dengan demikian, komponenkomponen mantel asam seperti laktat dan potassium yang berperan penting dalam menentukan $\mathrm{pH}$ kulit dapat terjaga.

Peningkatan $\mathrm{pH}$ kulit dapat mengakibatkan terjadinya inflamasi, penurunan kohesi stratum korneum dan penurunan permeabilitas pertahanan kulit yang akan memperburuk kondisi kulit, 
dimana kulit lebih muda mengalami luka,penampakan kulit tidak sehat, lebih mudah mengalami infeksi dan hidrasi kulit terganggu [18].

Dari hasil penelitian ini juga didapatkan bahwa masker gel peel-off ekstrak metanol kulit biji pinang yaki telah dibuktikan mampu mempertahankan $\mathrm{pH}$ kulit mencit jantan yang diberi paparan sinar UV sebagaimana yang terlihat pada tabel. Untuk dapat diaplikasikan dalam kehidupan sehari-hari, perlu dilakukan pengujian lebih lanjut tentang efek samping yang mungkin dapat ditimbulkan dari penggunaan sediaan masker gel peel-off ekstrak metanol kulit biji pinang yaki, terutama penggunaan pada kulit manusia.

\section{KESIMPULAN}

Berdasarkan hasil penelitian formulasi sediaan masker gel peel-off diperoleh hasil sebagai berikut:

Perbedaan konsentrasi ekstrak kulit biji pinang Yaki (Areca vestiaria Giseke) pada sediaan masker gel peel-off mempengaruhi efektivitasnya dalam melembabkan kulit dengan konsentrasi $10 \%$ menunjukkan efektivitas yang lebih baik dalam menjaga kelembapan kulit dengan perubahan nilai kadar $\mathrm{pH}$ kulit mencit mendekati $\mathrm{pH}$ normal rata-rata nilainya sebesar 6,194 setelah 28 hari pemakaian masker.

Ekstrak kulit biji pinang Yaki (Areca vestiaria Giseke) dengan konsentrasi 5\%, 7,5\% dan $10 \%$ dalam bentuk sediaan masker gel peel-off memiliki hasil yang homogen, dengan $\mathrm{pH}$ ratarata sebesar 5,6-5,92; lama waktu pengeringan 22,6-26,6 menit; daya sebar 5,53-5,97 cm; viskositas sebesar $11600-15000$ cps dan tetap stabil dalam penyimpanan 28 hari, paada pengujian iritasi sebagian besar tidak mengiritasi kulit wajah sukarelawan namun terdapat 1 sukarelawan mengalami iritasi.

\section{DAFTAR RUJUKAN}

1. Tortora, G. J.; B. Derrickson. Principles of Anatomy and Physiology. United States of America: John Wiley and Sons Inc. 2009, 123.

2. Wungkana, I.; Suryanto, E.; Momuat, L. Aktivitas Antioksidan dan Tabir Surya Fraksi Fenolik dari Limbah Tongkol Jagung (Zea mays L.). Jurnal Ilmiah Farmasi-UNSRAT. 2013(2), 149-155.

3. Flour, M. The Pathophysiology of Vulnerable Skin. Belgium: Dermatology Department University Hospital; 2009.

4. Suryanto Edi. Fitokimia Antioksidan. Putra Media Nusantara: Surabaya; 2012.

5. Simbala; H.E.I. Keanekaragaman Floristik dan Pemanfaatannya sebagai Tumbuhan Obat di Kawasan Konservasi II Taman Nasional Bogani Nani Wartabone (Kabupaten Bolaang Mongondow Sulawesi Utara). Disertasi tidak diterbitkan. Bogor: Institut Pertanian Bogor. 2006.

6. Mamonto, I. S., Runtuwene, M. R. J. dan Wehantouw, F. Aktivitas Antioksidan Ekstrak Kulit Biji Buah Pinang Yaki (Areca Vestiaria Giseke). Jurnal Ilmiah Farmasi - UNSRAT. 2014, 3, 263-272.

7. Filbert; Harry, S.J.; Max R.J.; Vanda, S. Penentuan Aktivitas Antioksidan Berdasarkan Nilai IC50 Ekstrak Metanol dan Fraksi Kulit Biji Buah Pinang Yaki (Areca Vestiaria Giseke). Jurnal MIPA-UNSRAT. 2014, 3, 149-154. 
8. Ariyanto, R. Uji Aktivitas antioksidan, Penentuan Kandungan Fenolik dan Flavonoid Total Fraksi Kloroform dan Fraksi Air Ekstrak Metanolik Pegagan (Centella asiatica L. Urban). Skripsi tidak diterbitkan. Yogyakarta: Fakultas Farmasi Universitas Gadjah Mada. 2006.

9. Depkes RI. Materia Medika Jilid V. Direktorat Jenderal Pengawasan Obat dan Makanan : Jakarta; 1989.

10. Lesmita R. Formulasi dan Uji Efek Anti-Aging Krim Ektrak Etanol Kubis Ungu (Brassica oleracea L.). Medan : Fakultas Farmasi, Universitas Sumatera Utara. 2017.

11. Sembiring, B.B., Ma'mun., Ginting, E. I. 2006. Pengaruh Kehalusan Bahan dan Lama Ekstraksi Terhadap Mutu Ekstrak Temulawak (Curcuma xanthorriza Roxb). Buletin Littro 17:53-58.

12. Vermerris, W.; Nicholson, R. Phenolic Compound Biochemistry, Springer, The Netherlands; 2006.

13. Miryanti Arr. Ekstraksi Antioksidan Dari Kulit Buah Manggis (Garcinia Mangostana L.) ; Bandung. 2011.

14. Tranggono, Retno I, Latifah, Fatmah. Buku Pegangan Ilmu Pengetahuan Kosmetik. Jakarta : PT. Gramedia Pustaka Utama; 2007.

15. Garg, A.; A. Deepika; S. Garg.;A. K. Singla. Spreading of Semi Solid Formulation. USA: Pharmaceutical Technology. 2002, 84-104.

16. Vieira, R. P.; Fernandes, A. R.; Kaneko, T. M.; Consiglieri, V. O.; Aparecida, C.; Oliveira, S. De; Velasco, R. Physical and physicochemical stability evaluation of cosmetic formulations containing soybean extract fermented by Bifidobacterium animalis. 2009, 45.

17. Chaverri, J. P.; L. M. R. Fermin; E. G. N. Amaya; M. O. Ibarra; O. N. M. Campos; O. G. Cuahutencos; I. R. Cruz ; R. Mata. ROS Scavening Capacity and NeuroprotectiveEffect of Alpha- Mangostine Againts 3- Nitropropionic Acid in Cerebellar Granule Neurons. Exp.Toxicol Pathol. 2009. Vol. 61(5): 491-501.

18. Ali, S.M ; G, Y. Skin pH: From Basic Science to Basic Skin Care. Acta Derm Venerol. 2013, 93: 261-267. 